術前診断に苦慮した非機能性膵ラ島細胞癌の 1 例

岡山済生会総合病院外科

藤原俊 哉 三 村 哲重 仁熊健 文
筒井 信 正 広瀨 周 平

症例は30歳, 男性. 心窝部痛を主訴に前医受診, 急性傽炎として加療された。脺炎の 改善後, 通院にて経過観察していたところ, 膵体尾部に腫痛を認めるようになったため, 当院紹介となった。造影 CT および造影 MRI 検查にて, 造影早期相で hypovascular で, 後期相で徐々に淡く染まってくる腫瘤を認めた. また, MRCPては主竍管の途絶と末梢 膵管の拡張を認めた。若年者ではあるものの膵管瀜を第一に疑い, 膵体尾部切除術を行 った。術後病理組織診断では膀ラ島細胞癌であった，免疫組織化学染色ではChromogranin Aのみ陽性であった. 膵内分泌腫埸は通常は圧排性に発育し, vascularity が高 いことが特徴である. 本症例は画像上, 非典型的なパターンを示し, 術前診断に難淽し た.

索引用語：膵内分泌腫瘍，非機能性膵亏島細胞癌，粨癌

緒 言

勝内分泌腫瘍は一般に多血性を示すことが多い.今 回,われわれが経験したのは乏血性腫湯であり,術前, 傽管癌を疑った。若千の文献的考察を加えて報告する。 症例

症例：30歳, 男性.

主訴: 心裔部痛.

家族歴・既往歴：特記事項なし.

飲酒歴：なし。

喫煙歴：20本/日，10年。

現病歴: 平成12年 1 月 31 日, 急性膵炎にて近医入院 加境。退院後, 外来通院していた. 炎症の改善後に施 行した ERPでは造影された膵管には不整像を認めな かった. 2 力月後の腹部 MRI で膵体尾部に SOLを指 摘され，9 月下旬頃より，心简部痛が出現した。腹部 CT では体尾部の SOL の大きさに変化を認めなかっ た. 10月17日，当院に入院した。

理学所見：結膜に負血，黄疸なし。左上腹部に軽い 圧痛を認めた他，著変はなかった。

血液生化学検査: 当院受診時, 白血球 $6,600 / \mu 1$,

2002年 8 月 9 日受付 2003 年 2 月 17 日採用

〈所属施設住所〉

于700-8511 岡山市伊福町 1-17-18
$\mathrm{CRP} 2.58 \mathrm{mg} / \mathrm{dl}$ と軽度上昇を認めた。血清アミラーゼ $466 \mathrm{IU} / 1$, 尿中アミラーゼ5,990IU/1 と上昇, 婳瘍マー カーは CEA, CA19-9は正常範囲内であったが,エラス ターゼは920ng/dl と高値を示していた。

内視鏡的膵管造影 (ERP)（図 1)：造影剤を多くは 注入しておらず尾側は造影されていないが，造影され た膵管には不整像を認めなかった。 retrospectiveにみ れば主脺管が途絶样にみえる。

腹部 CT ( 1 月〜 4 月)：1月31日, 急性膵炎発症時, 膆腫大と左傍結腸满に腹水の貯留を認めた。睡瘤など を指摘できなかった，4月1日の単純 CTでも腫熘を 指摘できなかった。

腹部 MRI 検查（5月29日）（図 2 ）：䐙体尾部に T1 強調像で明瞭な低信号域, T2強調像で等信号域の腫溜 を認めた。脺尾部は萎縮していた。Gd造影では腫瘤は 早期に周囲脺組織よりやや低信号域となり，静脈相て は徐々に等信号となり内部はやや不均一に造影され た。末梢側膵管の蛇行, 㹡張を認めた。

腹部造影 CT (図 3) - MRI 検査 (7月〜10月)：7 月24日, 造影 CT では, 同部の腫瘤の大きさは変わら ず, 早期相で膵組織と比べ低吸収域となり，晚期相で やや不均一な等吸収域となった. 尾部に pseudocyst を認めた。 末梢側膵管の蛇行, 拡張も持続していた. 10月10日の dynamic MRI ても同様に，30秒で膵組織 


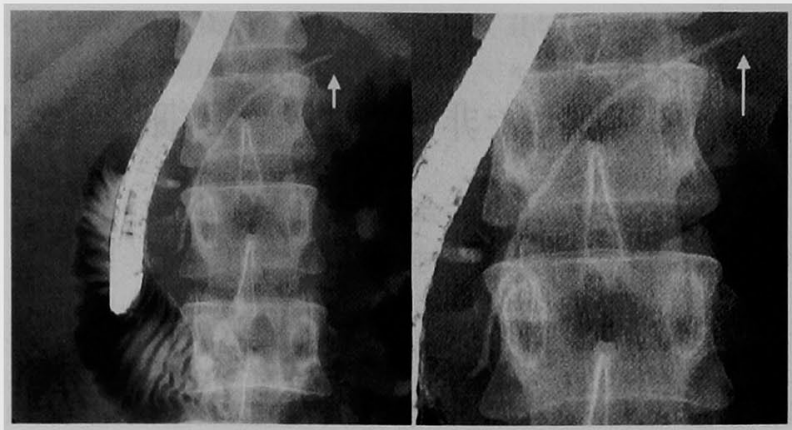

図 1 膵管造影：retrospective にみれば，」の部位で途絶していた。

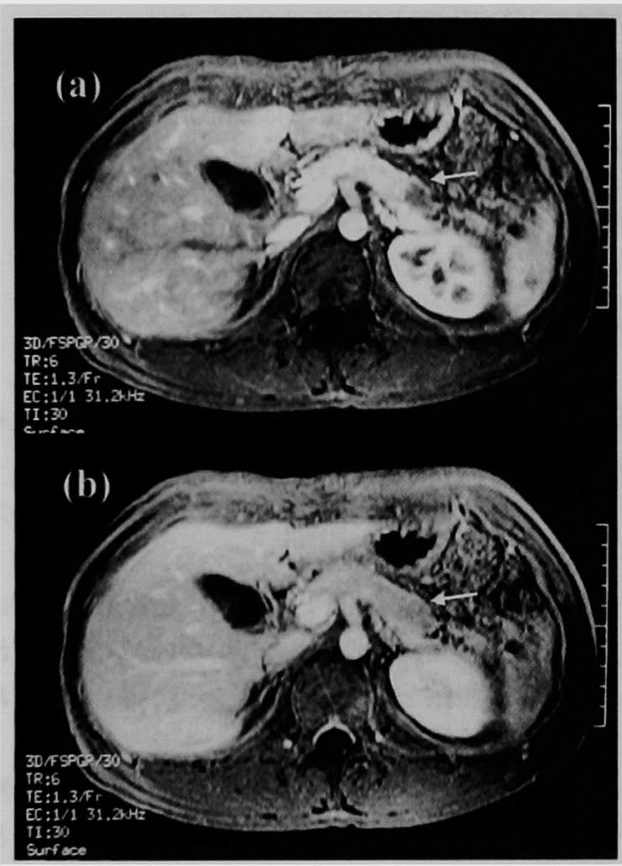

図 2 腹部造影 MRI 検查：a）早期相で】の部位に 膵組織より低信号の腫㝝を認めた。 b ) 後期相では 淡く造影され膵組織と等信号域となった。

より低信号となり，70秒後から徐々に染まり，3 分で ほほ等信号で内部はやや不均一に染まった。

$\operatorname{MRCP}($ 図 4)：腫瘤の位置と一致して, 主膵管は途 絶し，末梢㑡脺管が拡張していた. 胆道系に特に異常 を認めなかった。

血管造影検查：腫黈濃染はみられず，動脈系の en. casement は認めなかった. 門脈造影で脾静脈は頭側 より軽度圧排をうけていた。

年齢は若いものの, 以上の画像所見から膵管癌と第

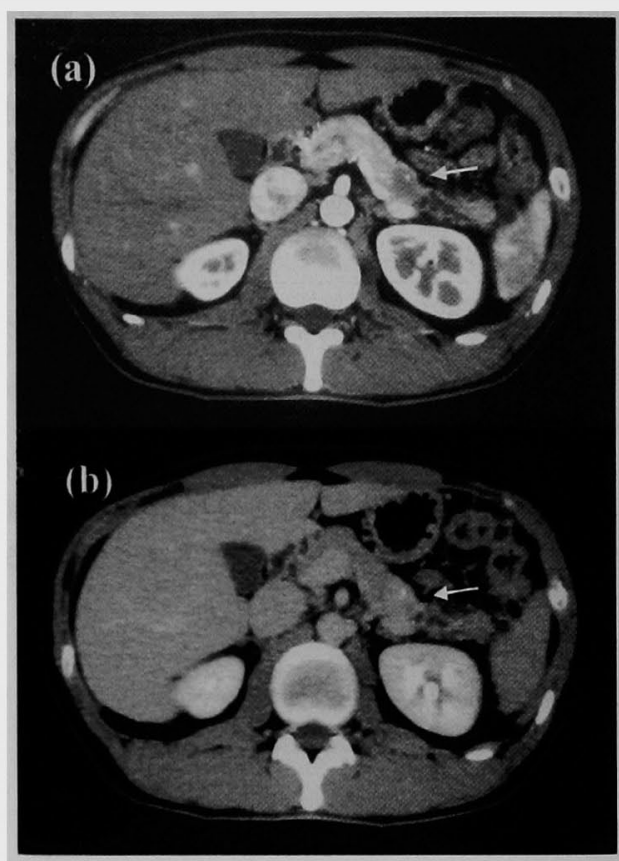

図 3 腹部造影 CT 検査：a）早期相でよの部位に膵 組織より低吸収域の腫瘤を䏰めた。 b) 平衡相では 淡く造影され膆組織と等吸収域となった。

一に考え，10月20日手術施行した。

手術所見：膵体尾部移行部に腫瘤を認め, 触診上, 腫瘤は比較的明瞭であった，穿刺吸引細胞診を行った ところ, 悪性細胞の検出はできず, 炎症細胞であった。 しかし, 膵前面の漿膜に dimpling があり, 肉眼所見か らは膵管癌を強く疑い, 切除して迅速組織検查に提出 するため, まず体尾部切除を行った。術中迅速組織検 查では小型の異型細胞を認め, 低分化腺癌の診断が得 られた。膵管癌に準じ, リンパ節郭清, 神経切除を追 


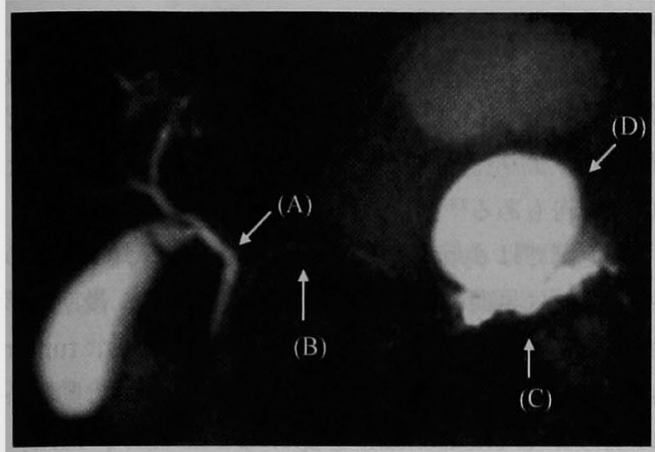

図 4 MRCP : 腫瘤の位置と一致して, 主膵管は途絶し, 末梢側膵管が搪張していた。

加した。術後診断では Pt ant TS1 $18 \times 15 \mathrm{~mm}$ 結節型 S1 Rp1 CH0 DU0 PV0 A0 PL(-) P0 H0 T2 N (一) M0 stage 根治度 A となった.

摘出標本 (図 5 ) : 割面では辺緑明瞭な淡黄色の腫瘤 を認め, 脾静脈への圧排を認めた。末梢側膵管の㹡張 と pseudocystを認めた。

病理組織検查（図 6 )：小型で異型性の比較的乏しい 細胞がみられ，やや好酸性の細胞質を有していた。 た，間質の著しい硝子化をきたし，比較的線維化に富 んでいた．前面槳膜への浸潤を認め, islet cell carcinoma と診断した。尾側の膵組織は線維化が強く, 慢 性膡炎をきたし，それに合併して pseudocystを認め た. 最終診断は islet cell carcinoma 葡様型 inf $\beta$ ly0 v0 ne0 d(-) se rp0 ply(-) pw(-) ew(-) t2 n0 curA. 免疫組織化学染色では Chromogranin A 陽 性であったが, 他 insulin, gastrin などは全て陰性であ り, non-functioning islet cell carcinoma と診断した. 術後, 概ね良好に経過, 第61病日に退院し術後 2 年 経過現在, 再発徴候なく通院加療中である.

\section{考 察}

膵内分泌腫瘍は一般に多血性で圧排性の発育を示す ことが多い. 今回われわれが経験した症例は膵管癌ま たは腫瘤形成性傽炎などを疑う画像所見を呈し，術前 診断に難渋した。

膵内分泌腫掦は膵腫㿠全体の $1 \sim 3 \%$ と比較的頻度 の少ない疾患であり，種々のホルモンを分泌して多彩 な症状を呈する機能性腫煬と臨床的・生物学的検索に おいてもホルモンの過剩分泌が証明できずに無症候性 に経過する非機能性腫場とに分類される1) 3)．そのう ち機能性腫場の insulinoma, gastrinoma が大半を占 め13), 非機能性腫湯は約15～50\%と報告によりばらつ

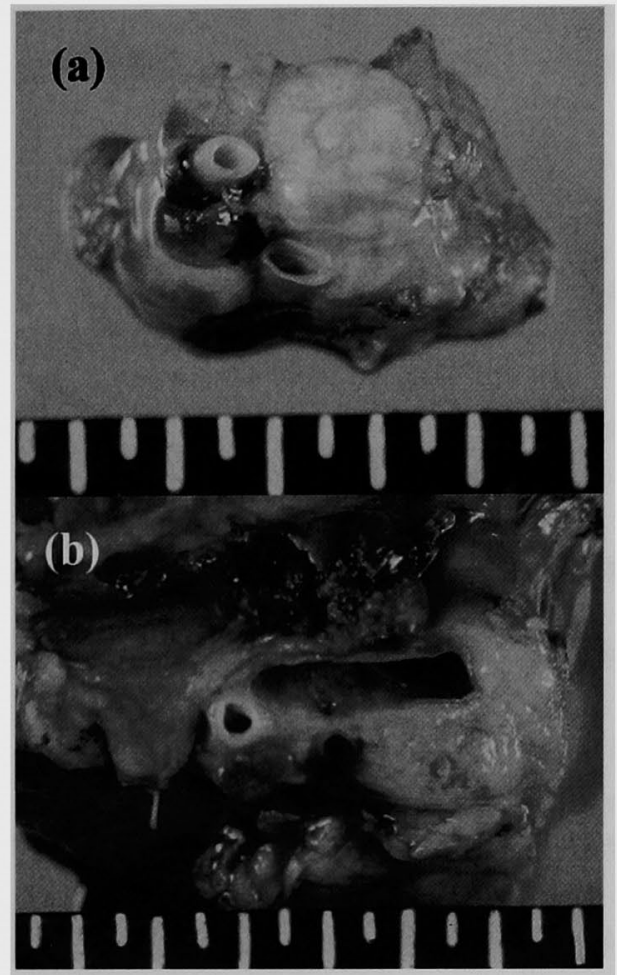

図 5 摘出標本：a）腫瘍部の割面；辺緑明瞭な淡 黄色の腫瘤を認めた. b) 末梢側に pseudocyst を 認め, 拡張した膀管を認めた。

きがみられる4)5.その臨床像は広い発症年齢分布を示 し，やや女性に多い傾向を認める．脺頭部への発生が 多く, 圧排性の発育のためか, 臨床症状を呈しにくい. 特に非機能性腫場の場合, $5 \mathrm{~cm}$ 以上の大きなものも 多くみられ，悪性の比率も 80-90\%と高(4)

臨床的な手段で診断可能なものは一般に機能性と考 元, 臨床症状や生化学的検査所見がなく腫瘍自体の形 態学的検索によってのみ内分泌腫場と診断されるもの は非機能性と考えられている21.膵内分泌腫湟の一般 的な画像的特徽としては, 造影 CT にて, 早期相で明 らかな腫煌濃染を示すものは73\%，平衡相で正常膆実 質の染まりが低下し腫嚐の存在が明らかになる例は 33 \%といわれる6. 晚期相での濃染は間質量が多い場合 にみられる6). MRIでは T1強調像で hypointensity, T2強調像で強い hyperintensityを呈し, dynamic MRI で早期にリング状に増強されることが多い81. 膵 管拡張は insulinoma などの機能性腫瘍ではほとんど なく, 非機能性缰掦では27\%に認められる6). ERCPは 悪性の指標となる所見が得られる場合もあるが，その 


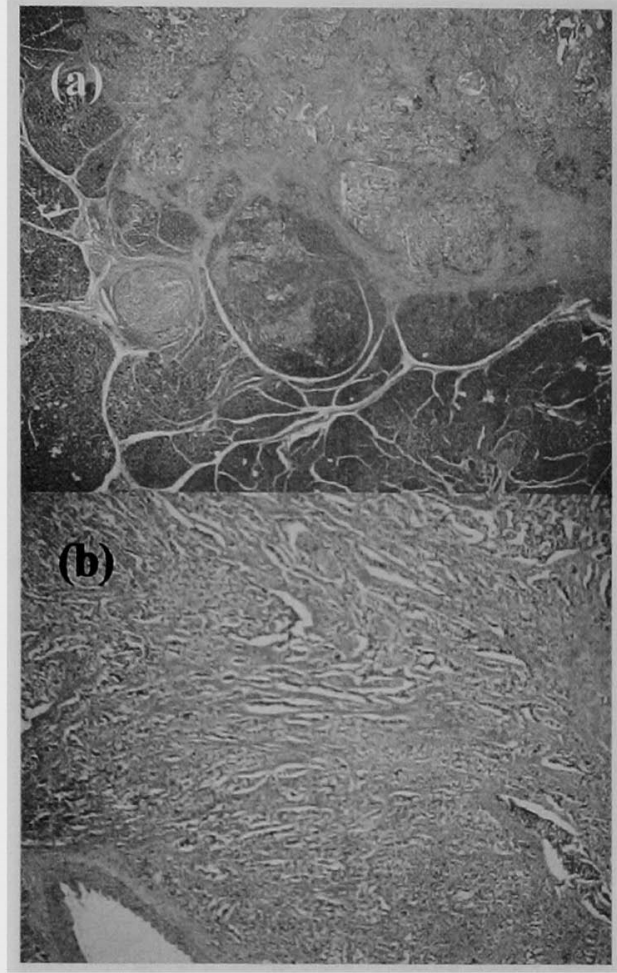

図 6 病理組较像 (HE 染色)：a）ルーペ像, b ) 40 倍.

診断においてあまり有用とされない(10).

それに比較して,膵管癌の画像的特徴は,造影 CT 早 期相て膡実質は造影されて high density を呈するが 癌巣は vascularity がそしいため low density mass と して描出される ${ }^{11121} .4 .8 \% か^{\prime}$ 後期相で周囲膵組織と同 等に染まってくる ${ }^{12)}$. 線維化に富む癌巣は晚期相で造 影斉の貯留が起こるためhigh densityに描出され る(1). MRI もCT と同様に造影早期相で脺実質と比べ て hypointensity mass として描出される゙1. ERCP て は主膵管の限局性狭窄や途絶, 膵頭部例での胆管狭窄 を示し，不整な V 字狭窄を示す. 尾側䏾管の㹡張は78 \%と高率にみられる ${ }^{13)}$.

腫瘤形成性膆炎はそもそも胼管癌類似の限局性腫瘤 を呈する膵炎に対して㥧用的に広義に用いられ，多彩 な画像所見を呈する ${ }^{14)}$. 正診率は30\%と非常に低( ${ }^{12)}$. 画像的な特徵は,造影 CT では早期相で淡く造影され, 後期相で内部不均一に造影される。約 $50 \%$ が周囲膵組 織と同様に染まる，ERCPでは腈癌よりやや低率に主 膵管の限局性狭窄や途絶, 胆管狭窝が出現するが, 脺 癌に比して平滑狭姩が多い ${ }^{13)}$. 膵管と胆管の狭窝所見
の併存率は比較的少ないといわれる ${ }^{13)}$. また penetrating signや 2 次分枝の良好な描出が特徴である ${ }^{13)}$. 最 近では膵癌との鑑別において CT angiographyなど 行えば,より特徴的な所見を得ることが可能であると いう報告もある12).

本症例では dynamic CT および dynamic MRI での パターンは早期に膵実質より低濃度であり, 後期に脺 実質同等に染まるという傾向を示すものの, tumor stain というほど濃染しなかった.血管造影では動脈系 の明らかな encasement を認めなかったが, MRI, MRCP での膵管狭寉と末梢膵管拡張の所見から浸潤 と診断した. 若年者であり，画像所見上も典型的では ないが,脺癌を疑うには充分な所見であったといえる。

病理組織学的な診断にはChromogranin $A$, Synaptophysin, Glimeliusなどの免疫染色を要する が, 機能性, 非機能性の診断および良悪性の診断はか なり困難である415)，遠隔転移，リンパ節転移または脈 管侵襲や被膜浸潤, 神経浸潤の有無が根拠となる。非 機能性膵島腫瘍は悪性の比率が高く, 比較的腫湟が大 きくなってから見つかることが多いが, 腫湟径自体は 良悪性とは無関係とされ，小腫咟の悪性例の報告も散 見される ${ }^{10)}$. 本症例でも $18 \mathrm{~mm}$ と小径であるにもかか わらず，被膜浸潤を認め，画像上も膵管狭窄を示し悪 性が同えた．それらの所見が得られず，腫瘍径が小さ くても，また明らかな浸潤の所見がなくとも，基本的 には potentially malignancy ということを常に考虑 しなくてはならない215).一般に線維性被膜に囲まれ,充 実性腫瘍で毛細血管に富むもの, 線維化を呈し疫痕様 を示すもの, 粘液水腫様変性, 壊死あるいは出血を伴 い偽婁腫状を呈するもの, 膵外性の発育を示すもの等

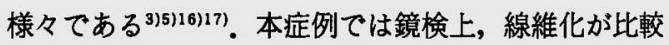
的多くみられた。このことが膵管癌と類似した造影パ ターンを呈した原因かと推測される.

今回われわれが経験した症例は非機能性腫瘍, 非典 型的画像，若年者，脺炎の治療歴など様々な要因によ り，診断に非常に難涉した。膵管狭窄の所見から悪性 の診断を得て, 外科的切除を選択するに至ったが, 術 前に膵内分泌腫瘍であるという診断は不可能であった と考える。

\section{結語}

1. 非機能性膵ラ島細胞癌の 1 例を経験した。

2. 膵内分泌腫場の所見として典型的ではなく, 術 前診断は困難であった。

本論文の投稿にあたり，病理学的見地から御助言を賜つ 
た当院病理部の能势聡一郎先生に謝意を表します。

文献

1）山崎健太郎，川原田嘉文：膵内分泌腫瘍一インス リノーマ・ガストリノーマほか一.外科治療 82 ： 887-896, 2000

2）栗原克己，永井秀雄，笠原小五郎地：臆内分泌腫

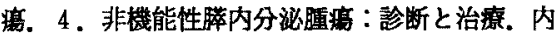
分沴外科 $15: 109-115,1998$

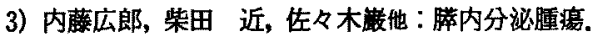
1. 機能性腫湯. 外科 $62: 1034-1039,2000$

4）梗澤司, 宮坂信雄, 諸星利男他: 睟内分泌腫瘍 の病理形態学的特徵と良悪性晾断. 胆と膆 20 : 133-137, 1999

5）鉿木 大, 山森秀夫, 田代垔彦地：膵外性に発育

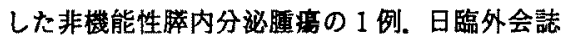
$62: 2785-2789,2001$

6）上野恵子, 本柳嘉信, 羽鳥 隆他：ヘリカルCTに

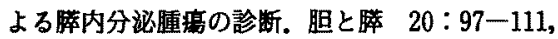
1999

7) 伊豆蔵正明, 宮田正彦: 脺島腫瘍一脺癌の治療法 の選択一。臨外 $47: 1045-1052,1992$

8）石原 武, 山口武人, 谷嶋隆之他：MRIによる傽

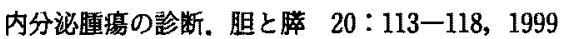

9）高烟俊一, 難波江俊永, 西山菁一他：内視鏡的逆

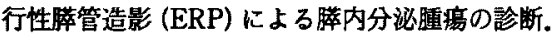
阳と膵 $20: 127-132 ， 1999$
10）山崎真敬, 滝沢 建, 市川 雅他: 主脺管狭窄を 呈した非機能性小脺島細胞腫の 1 例. 日臨外会誌 $63: 1005-1008,2002$

11）高安蜸一，村松幸男：CT \& MRIによる肝・胆・ 膵の画像診断. メディカルトリビューン, 東京, 1993, p103-135

12）安藤達也，山中若樹，田中涉他：腫嘴形成性脺 炎と脺炎の術前鑑別診断について，胆と脺 20 ： $513-518,1999$

13）小林 㴊, 藤田直孝, 野田 裕地：ERCP と EUS による腫瘤形成性膵炎の䛦断.胆と膵 $20 ： 285$ 292,1999

14）中澤三郎：腄瘤形成性脺炎の疾患概念。胆と脺 $20: 269,1999$

15）上田貴威, 狩峰信也，上尾裕昭他：非機能性ラ氏 島湩痛の一切除例. 大分病医誌 $29: 134-137$, 2000

16) Kato $K$, Kondo S, Ambo $Y$, et al : Nonfunctioning endocrine tumor of the pancreas with extrapancreatic growth and cyst formation: report of a case. Surg Today 30:651-654, 2000

17）武田和永，鬼頭文彦，高橋正純地：宾胞形成を伴 った非機能性䐁ランゲルハンス島細胞絽の1 例. 日臨外会誌 $62 ： 2790-2793,2001$

\title{
A CASE OF NONFUNCTIONING ISLET CELL TUMOR WITH DIFFICULTY IN PREOPERATIVE DIAGNOSIS
}

\author{
Toshiya FUJIWARA, Tetsushige MIMURA, Takefumi NIGUMA, \\ Nobumasa TSUTSUI and Syuhei HIROSE \\ Department of Surgery, Okayama Saiseikai General Hospital
}

A 30-year-old man complained of epigastralgia, and treated with a diagnosis of acute pancreatitis elsewhere was found to have a tumor in the body of the pancreas while following after discharge. He was referred to the hospital. Enhanced CT and enhanced MRI scans showed a hypovascular tumor on early phase, that was slightly enhanced on late phase. MRCP showed stricture of the main pancreatic duct with dilatation. Distal pancreatectomy was performed under a diagnosis of pancreatic ductal cancer. Histopathological diagnosis was islet cell tumor with microscopic invasion of serosa. Immunohistochemically, tumor cells were positive for only Chromogranin A. We finally diagnosed this case as primary, malignant nonfunctioning islet cell carcinoma. In this case, imagings disclosed untypical patterns so that we have great difficulty in preoperative diagnosis. 